\title{
Reproductive biology of a population of Gymnotus aff. carapo (Teleostei: Gymnotidae) from southern Brazil
}

\author{
Diego de Paula Cognato and Clarice Bernhardt Fialho
}

\begin{abstract}
The reproductive period and its relation with somatic and abiotic factors, the relative and absolute fecundity, spawning type, length of first maturation and sex ratio is describe for Gymnotus aff. carapo from a small lake at Itapuã State Park, Rio Grande do Sul, Brazil. Gymnotus aff. carapo presents a relatively long reproductive cycle extending from November/2003 to March/ 2004. Decreases in water conductivity and increases in dissolved oxygen are correlated with increased gonadal development in males. In females, seasonal increases in temperature and photoperiod and decreases in dissolved oxygen are correlated with increased gonadal development. The mean absolute fecundity was 915.3 oocytes, and mean relative fecundity 0.20 oocytes/ $\mathrm{mg}$ body weight. Egg size distributions indicate multiple spawning. The size of first maturation was $141 \mathrm{~mm}$ in females and 146 $\mathrm{mm}$ in males. The sex ratio was $1: 1$, with a male bias only in smaller size classes.

São descritos o período reprodutivo e a relação deste com fatores bióticos e abióticos, a fecundidade absoluta e relativa, o tipo de desova, comprimento de primeira maturação e proporção sexual de Gymnotus aff. carapo de um pequeno lago no Parque Estadual de Itapuã, Rio Grande do Sul, Brazil. A espécie apresentou um período reprodutivo relativamente longo, de novembro de 2003 até março de 2004. Houve correlação significativamente positiva entre o IGS dos machos e o oxigênio dissolvido e negativa em relação à condutividade. O IGS das fêmeas se correlacionou positivamente com a temperatura e fotoperíodo, e negativamente com o oxigênio dissolvido. A fecundidade absoluta média foi de 915,3 ovócitos e a fecundidade relativa média foi de 0,20 ovócitos por miligrama de peso da fêmea. A desova foi considerada parcelada e o tamanho de primeira maturação gonadal foi de $141 \mathrm{~mm}$ para fêmeas e $146 \mathrm{~mm}$ para machos. A proporção sexual no período amostrado foi de 1:1, sendo que somente na menor classe de comprimento houve maior abundância dos machos.
\end{abstract}

Key words: Gymnotiformes, Eletric fishes, Reproduction, Neotropical.

\section{Introduction}

Weakly electric fishes of the order Gymnotiformes, known in Brazil as "sarapós" and "tuviras", have the remarkable ability to generate and detect electric fields (Bennett, 1971). This ability enable these fishes explore their habitat, communicate with conspecific and perceive objects and other creatures in the environment.

Gymnotiforms have a wide geographical range throughout lowland South and Central America and occur in every conceivable aquatic habitat, including river channels, floodplains, flooded forests, forest streams, cataracts, swamps, coastal creeks and estuarine reaches (Albert \& Crampton, 2003). Gymnotus is an air breather and is able to tolerate hypoxic environments (Crampton, 1998). Lundberg \& Weber
(1987), Crampton (1996) and Mago Leccia (1994) emphasize the importance of gymnotiforms in South American lowland aquatic ecosystems.

Gymnotus has the widest geographical range of all gymnotiform genera, occurring throughout lowland South and Central America from río Salado in the Argentinean Pampas to the río San Nicolas, Mexico. It also occurs in the Caribbean island of Trinidad. Gymnotus species are aggressive nocturnal predators of fishes and other small aquatic animals (Albert \& Crampton, 2003). Kirschbaum \& Wieczorec (2002), Kirschbaum \& Schugardt (2003) and Crampton \& Hopkins (2005), describe parental care behavior in Gymnotus species.

Few studies have brought biological aspects of gymnotiforms. Kirschbaum (1979) has investigated the reproduction of Eigenmannia virescens in captivity. It describes

Departamento de Zoologia, Laboratório de Ictiologia, Universidade Federal do Rio Grande do Sul, A. Bento Gonçalves, $9500,90501-970$ Porto Alegre, RS, Brazil, e-mail: diegocognato@gmail.com 
that a decreasing in conductivity and $\mathrm{pH}$, and increasing of water level and rain simulation led to gonadal recrudescence. Barbieri \& Barbieri (1982, 1983a, 1983b, 1984a, 1984b, 1984c, 1985) made a broad investigation of Gymnotus carapo in Represa do Lobo, São Paulo, Brazil, emphasing aspects of life history. They described the reproductive cycle occurred between October and December, the spawning type is multiple, fecundity can reach 3000 oocytes, growth is related to time confirming that natural "age classes" (periodic spawns) occurs, and describe gonadal histology of males and females. A nutritional dynamics study showed that the fishes exhibited better feeding conditions after the reproductive season. The distribution of the gonadosomatic index of Gymnotus carapo in Represa do Lobo was related to the variations of water temperature, concentration of dissolved $\mathrm{O} 2$, rainfall and photoperiod.

Curtis \& Stoddard (2003) studied the mating preference in female electric fish Brachyhypopomus pinnicaudatus. The electric organ discharge signals of chosen males had larger amplitudes and longer durations. Kirschbaum \& Schugardt (2003) investigated the reproductive strategies and developmental aspects in mormyrid and gymnotiform fishes. For these authors, Sternopygus macrurus exhibited parental care with males guarding the eggs, whereas males of Gymnotus carapo revealed to be mouthbreeders (guarding free embryos). Gonad maturation seems to be provoked by increase of conductivity in all mormyrid species tested and in several gymnotiform species.

Vazzoler (1996) brings information about reproductive biology of G. carapo, Eigenmannia trilineata and E. virescens, and describes multiple spawning and parental care in $G$. carapo and E. trilineata. Silva et al. (2003) studied the biogeography and breeding of Gymnotiformes from Uruguay. The presence of sexually mature males and females of Brachyhypopomus pinnicaudatus, and a sudden increase of juveniles indicated the occurrence of the breeding season in November, December, and January, coinciding with high mean water temperatures and extreme photoperiod in the site of study. Giora (2004) studied E. trilineata, emphasing reproductive cycle is relatively long, between October and February, with multiple spawning. The mean absolute fecundity was 1025 oocytes, size of first maturation $8.05 \mathrm{~cm}$ for females and $6.35 \mathrm{~cm}$ for males, and sex ratio $1: 1$. The gonadosomatic index of E. trilineata was correlated with photoperiod and conductivity.

The comparison of the reproductive biology of the Gymnotus species studied herein with data of G. carapo from the literature is complicated by the scarce knowledge of the diversity of the genus in the Southern portion of South America. The specific name G. carapo has been largely used in a broad sense, and seems to refer to more than one species in the literature. Albert \& Crampton (2003) have recently redescribed "Gymnotus carapo, sensu stricto" and restricted its distribution to the Amazon and Orinoco Basins below c. $500 \mathrm{~m}$ elevation, the Island of Trinidad, drainages of the Guyanas Shield, and Atlantic drainages of northeastern Bra- zil (including the rios Pindaré, Itapicuru and Parnaíba). Such a distribution excludes the populations studied by Barbieri \& Barbieri (1982, 1983a, 1983b, 1984a, 1984b, 1984c, 1985), Vazzoler (1996), and Silva et al. (2003).

The species studied herein belong to the G. carapo species-group in the sense of Albert (2001), by possessing a clear or pale patch near the caudal end of the anal fin, two laterosensory pores in the dorso-posterior portion of preopercle in the prepercular-mandibular canal, and is therein referred as Gymnotus aff. carapo. We investigate the reproductive biology of a population from a small lake in Itapuã State Park, Rio Grande do Sul, Brazil. Emphasis is given on the reproductive cycle and its relation to biotic and abiotic factors, absolute and relative fecundity, spawning type, size of first maturation, and sex ratio.

\section{Material and Methods}

\section{Site of study}

The Itapuã State Park is located $57 \mathrm{~km}$ south from Porto Alegre, in Viamão municipality. It was created in 1973, due to a strong ecological mobilization against the destruction of the landscapes and natural environments caused by granite extraction. The Park has extreme biological importance because its $5.550 \mathrm{~h}$ host a diverse biota, and because it is one of the last fragments of natural environment in the Porto Alegre region.

The lagoa Verde $\left(30^{\circ} 22^{\prime} 52.4^{\prime \prime} \mathrm{S}, 51^{\circ} 01^{\prime} 25^{\prime \prime} \mathrm{W}\right)$ is situated between the Morro do Campista, Morro da Grota and the laguna dos Patos. It is a shallow lake, less than $1 \mathrm{~m}$ deep, with muddy sediment, dark water and abundant vegetal biomass, including Ludwigia peploides (Onagraceae), Utricularia spp. (Lenticulariaceae), Nymphoides indica (Menyanthaceae), Pontederia lanceolata (Pontederiaceae), Azolla sp. (Azollaceae), Eliochares sp. (Ciperaceae), Cabomba australis (Cabombaceae), Echinodorus sp. (Alismataceae), Lemna valdiviana (Lemnaceae), Scirpus sp. (Sciperaceae) and abundant grass in the shores. There is a considerable seasonal variation of water volume, occasionally connecting to a neighboring small lake to form a single flooded area. The lake is surrounded by Atlantic Forest vegetation. Two species of gymnotiforms occur in the lagoa Verde, $G$. aff. carapo and an undescribed species of Brachyhypopomus.

\section{Samples}

The specimens were collected monthly between May and November/2003 and fortnightly between December/2003 and April/2004, using a dip net and an electric fish locator that converts the electric field into sound. Samples were taken between 9:00 and 12:00 a.m. among vegetation, and the specimens were immediately transferred to $10 \%$ formalin solution. Voucher specimens were deposited in the fish collection of Departamento de Zoologia of the Universidade Federal do Rio Grande do Sul, Porto Alegre, Brazil. (UFRGS 6854, UFRGS 6855, UFRGS 6856, UFRGS 6857, UFRGS 6858, UFRGS 6859). 
The following water quality parameters were taken at fixed locations: oxygen saturation (with an OXI 330/SET-WTW oxygen meter), conductivity (LF330/SET-WTW conductivity meter), water temperature (conventional thermometer), and depth. Rainfall data were obtained from a local meteorological station ( $8^{\circ}$ Distrito de Meteorologia - Serviço de Observação e Meteorologia Aplicada de Porto Alegre). Photoperiod data were obtained using software SkyMap Pro 9.0.

\section{Analysis}

After 10 days, specimens were transferred to $70^{\circ}$ alcohol, and total length (Lt) in millimeters and body weight (Wt) in grams were measured. Gonadal weight $(\mathrm{Wg})$, liver weight $(\mathrm{Wl})$ and stomach weight (Ws) were measured (in grams) following dissection. The sex and gonadal maturation classes were estimated according to macroscopic features such as color, presence of blood vessels, presence of oocytes and size of the gonad (see Vazzoler, 1996; Barbieri \& Barbieri, 1984b, 1985).

Gonadal maturation classes were validated using histology of gonads of 40 ovaries and 70 testes embedded in paraffin or glycolmethacrylate resin. Sections were of 5-7 $\mu \mathrm{m}$ and were stained with hematoxylin and eosin $(\mathrm{H} \& \mathrm{E})$.

Gonadosomatic Index $(\mathrm{IGS}=(\mathrm{Wg} \times 100) / \mathrm{Wt})$, Stomach Repletion Index $(\mathrm{IR}=(\mathrm{Ws} x \mathrm{100}) / \mathrm{Wt})$ and Hepatosomatic In$\operatorname{dex}(\mathrm{IHS}=(\mathrm{Wl} \times 100) / \mathrm{Wt})$ were calculated, representing the percentage of the organ weight in relation to total fish weight.

The reproductive cycle was determined through the analysis of the relative frequencies of gonadal maturation classes, as well as the monthly variation of IGS mean values calculated by the equation: IGS $_{\text {mean }}=\sum I G S / n$ where IGS $=$ gonadosomatic index of each reproductive specimen (excluded immature), and $n=$ number of reproductive specimens.

The relative frequencies of gonadal maturation classes of fortnightly samples were grouped.

The non-parametric Spearman Rank correlation test was applied between IGS monthly mean values and IR, IHS, temperature, conductivity, dissolved oxygen, depth, rainfall and photoperiod values to verify the possible relationships between the reproduction and biotic/abiotic factors.

The ovaries of 10 mature females were immersed in Gilson's solution to estimate absolute fecundity of the species, according Vazzoler (1996). All yolky oocytes were counted under a stereomicroscope after the oocytes release from ovarian tissue. According to Adebisi (1987), the relative fecundity was calculated as the number of oocytes per milligram of female's total body weight.

The spawning type was estimated through the analyses of 30 ovaries representing the different gonadal classes. In each ovary, 150 oocytes were sampled and measured considering their largest diameter (Vazzoler, 1996). Measurements were taken using a scale in the stereomicroscope.

The sex ratio was estimated using the absolute frequency of males and females during the sampling period. The Chisquared test $(\alpha=0.05)$ was applied monthly and by length classes to verify significant differences in sex ratio during sampling period.
The size of first maturation of males and females was estimated according to the distribution of relative frequencies of young and adult fishes by length classes (Vazzoler, 1996). These curves were adjusted according the following equation: $\mathrm{Fr}=1-\left(e-\mathrm{aL} \mathrm{t}^{\mathrm{b}}\right)$, where $\mathrm{Fr}$ stand for relative frequency of adult individuals; and $e$ is the base of the natural logarithm; Lt is total length and $a$ and $b$ are estimated constants related to curve adjustment. The size of the first maturation is defined as the length class in which $50 \%$ of individuals are considered adults (Vazzoler, 1996).

The gonadal maturation classes were defined as immature, maturing, mature, spawning, and spent for females and as immature, maturing, mature, and spent in males.

\section{Results}

A total of 388 specimens of $G$. aff. carapo were captured: 177 females $(42.7-281.8 \mathrm{~mm} \mathrm{Lt})$ and 211 males $(41.6-280.7 \mathrm{~mm}$ Lt) (not including larvae, as defined by Nakatani et al., 2001).

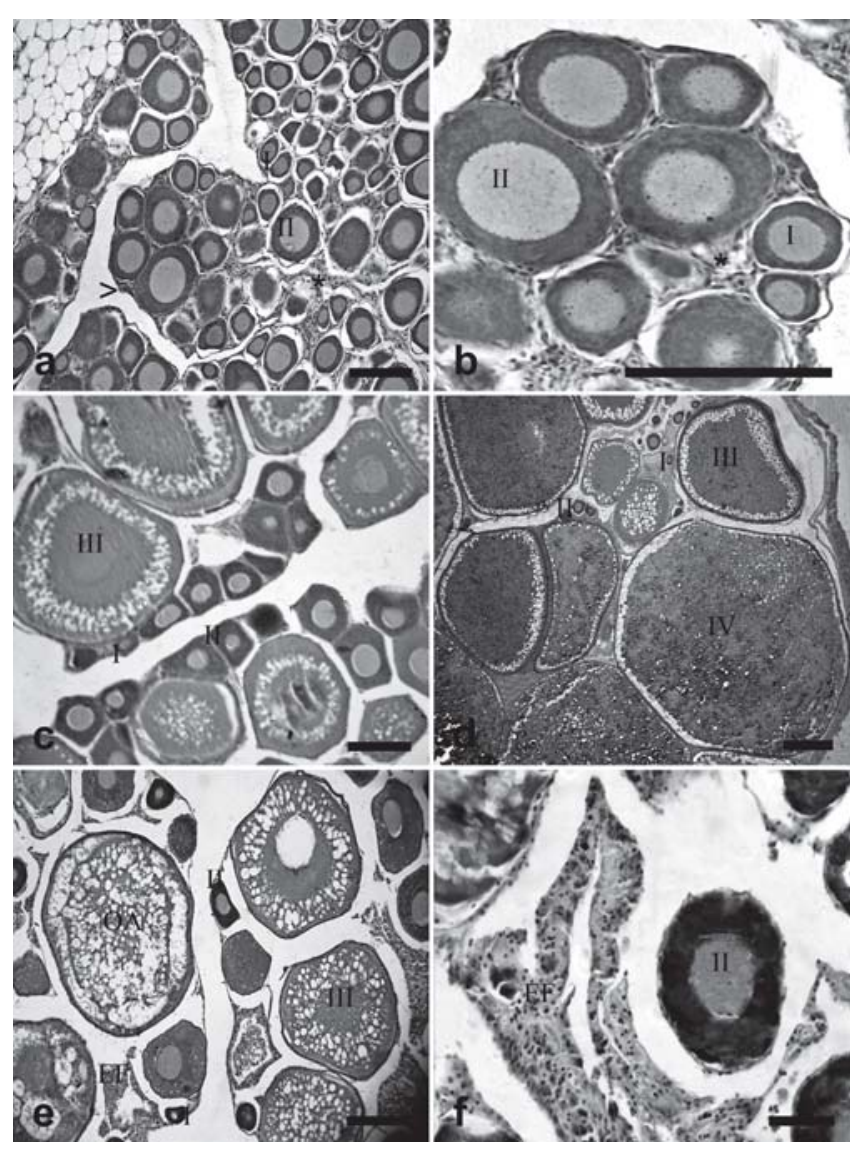

Fig. 1. Histological sections showing five gonadal maturation stages of Gymnotus aff. carapo ovary. a) Immature (10X); b) Immature ovaries in detail (15 X); c) Maturing (10X); d) Mature (4X); e) Spawning (10X); f) Spent (10X). Arrowhead Tunica albuginea; Asterisk - connective tissue. Stages of oocyte development: I, II - reserve oocytes; III - Yolk vesicle oocytes; IV - Mature oocytes; OA: Oocytes-in-absorption; EF: Empty follicle. Scale bar $=500 \mu \mathrm{m}$. 

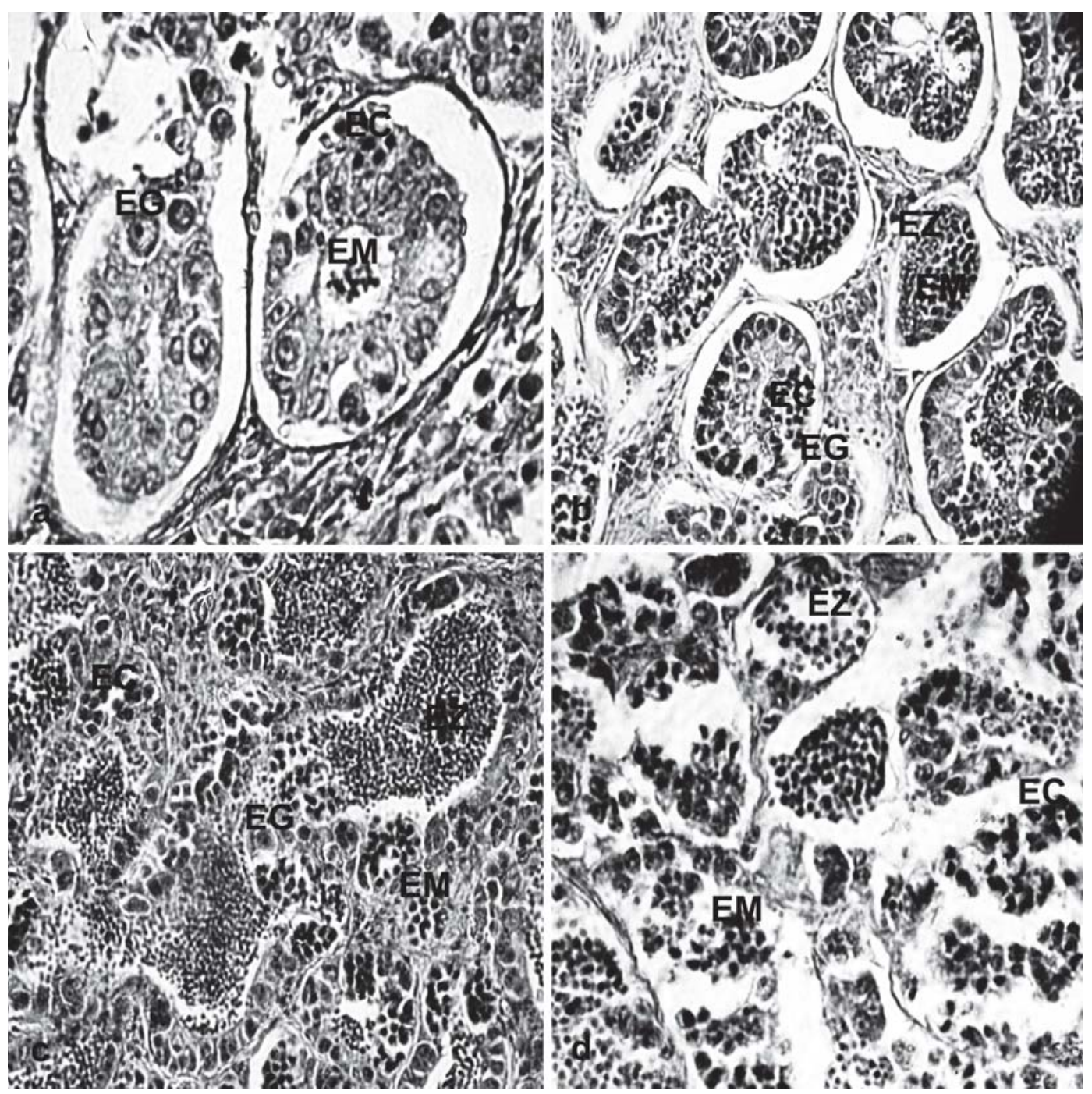

Fig. 2. Histologic sections of four different gonadal maturation stages of male Gymnotus aff. carapo. a) Immature (40 X); b) Maturing (40 X); c) Mature (40 X) d) Spent (40 X). EG: spermatogonia; EC: spermatocytes; EM: spermatids; EZ: spermatozoa.

The gonads of immature females are small, occupying less than $1 / 3$ of body cavity in length, swollen, flattened and translucent. In the histological sections, ovaries are covered with a thin tunica albuginea of connective tissue. Branches from this connective tissue form the stroma, supporting only reserve oocytes (stage I, II) (Figs. 1a - b). Connective tissue can be observed between oocytes.

Maturing females have small ovaries, occupying $1 / 3$ of body cavity in length. The color is pink due to blood vessels. Surface is irregular, and the oocytes are observed with the naked eye. In the histological sections, reserve oocytes (stage I, II) are observed and yolk vesicle oocytes (stage III) increase in number during the maturing process (Fig. 1c).

Mature females present large rigid half-coned shaped gonads, occupying half or more of the body cavity in length. The color is yellowish, with opaque and translucent oocytes clearly visible to the naked eye. In sections, yolk vesicle oocytes (stage III) and mature oocytes (stage IV) are observed, along with small reserve oocytes (stage I, II) (Fig. 1d).
Spawning females show flabby pink ovaries (commonly occupying half of the body cavity in length), and residual oocytes. In sections, oocytes in different stages of development (stage I, II, III), empty follicles and oocytes-in-absorption can all be observed (Fig. 1e). Connective tissue between oocytes can be observed.

Spent females have long yellowish or pink gonads occupying more than half of the body cavity in length, with hemorrhagic zones and small oocytes. In sections a general disorganization of tissue are visible, as well as reserve oocytes (stage II) and empty follicle (Fig. 1f).

Immature males have translucent testes, occupying less than half of body cavity in length. In histological sections, spermatogenic tubules show basically spermatogonia and few spermatocytes and spermatids (Fig. 2a). A large amount of stroma can be observed between spermatogenic tubules.

Maturing males have small testes, sometimes occupying half of the body cavity in length. They are more opaque than immature testes. In sections, cells in different stages of de- 
Table 1. Correlations based upon Spearman's rank test between mean gonadosomatic index (IGS) of Gymnotus aff. carapo and somatic factors in lagoa Verde, Itapuã State Park.

\begin{tabular}{cccc}
\hline \multicolumn{2}{c}{ Gonadosomatic index and somatic factors } & $\mathrm{r}$ & $\mathrm{p}$ \\
\hline \multirow{2}{*}{ IGS x IR } & Males & 0.1853 & 0.4921 \\
& Females & -0.1147 & 0.6723 \\
\multirow{2}{*}{ IGS x HS } & Males & 0.0882 & 0.7452 \\
& Females & 0.1745 & 0.5204 \\
\hline
\end{tabular}

velopment, and lobes partially filled with spermatids and spermatozoa are visible (Fig. 2b). Stroma is observed between spermatogenic tubules.

Mature testes are opaque and white, and occupy half of the body cavity in length. In sections, a connective tissue covers spermatogenic tubules externally. Spermatogonia, spermatocytes and spermatids can be observed, as well as a large amount of spermatozoa in spermatogenic tubules (Fig. 2c). Few stroma is observed between spermatogenic tubules.

Spent males present white and sometimes pink testes occupying $1 / 3$ of the body cavity in length. In sections, spermatogenic tubules are disorganized, and spermatogonia, spermatocytes and spermatozoa are observed (Fig. 2d). Few stroma is observed between spermatogenic tubules.

Reproductive period started in November/2003 extending to March/2004, and females showed higher mean IGS values in January/2004 (Fig. 3). High frequency of mature females between November/2003 and March/2004 confirmed data of IGS curve (Fig. 4). Immature females were captured in all months of the sampling period, and maturing females in the whole sampling period except for January and February/2004. Spawning females were captured from November/2003 to February/2004 and spent in March and April/2004 (Fig. 4).

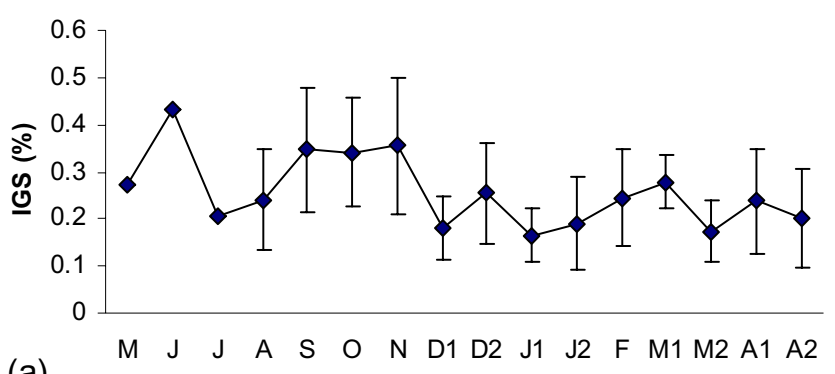

(a)

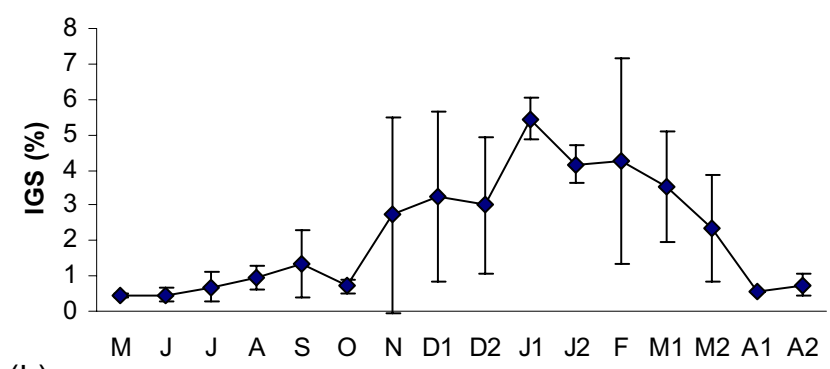

(b)

Fig. 3. Monthly variation of mean gonadosomatic index Gymnotus aff. carapo in lagoa Verde, Itapuã State Park, between May/2003 and April/2004. (a) Males, (b) Females. Vertical bars are standard deviation from mean.
Table 2. The non-parametric Spearman test between mean gonadosomatic index (IGS) of Gymnotus aff. carapo and abiotic factors in lagoa Verde, Itapuã State Park. Significant values are in bold $(\mathrm{p}<0.05)$.

\begin{tabular}{llcc}
\hline Gonadosomatic index and Abiotic factors & $\mathrm{r}$ & $\mathrm{p}$ \\
\hline \multirow{2}{*}{ IGS x Temperature } & Males & -0.4665 & 0.0665 \\
& Females & 0.7138 & $\mathbf{0 . 0 0 1 9}$ \\
IGS x Conductivity & Males & -0.5235 & $\mathbf{0 . 0 3 7 4}$ \\
& Females & 0.0735 & 0.7867 \\
\multirow{2}{*}{ IGS x Dissolved oxygen } & Males & 0.5471 & $\mathbf{0 . 0 2 8 3}$ \\
& Females & -0.7118 & $\mathbf{0 . 0 0 2 0}$ \\
IGS x Depth & Males & 0.3402 & 0.1972 \\
& Females & -0.4201 & 0.1052 \\
\multirow{2}{*}{ IGS x Rainfall } & Males & 0.1770 & 0.5120 \\
\multirow{2}{*}{ IGS x Photoperiod } & Females & -0.1003 & 0.7117 \\
& Males & -0.2971 & 0.2600 \\
& Females & 0.7941 & $\mathbf{0 . 0 0 0 2}$ \\
\hline
\end{tabular}

The higher means of the gonadosomatic index in September, October and November suggests that males were ready for reproduction before females. Mature males were observed throughout the reproductive cycle, especially in December/ 2003, January and March/2004. Even when the mean gonadosomatic index was lower after November/2003, mature males were present in the population. In May, June, and July/2003 just one reproductive male was sampled each month. Immature and mature males were captured during the whole sampling period, and spent males were sampled in November-December/2003 and in January, February, and March/2004 (Fig. 4).

\section{$\square$ Imature $\square$ Maturing $\square$ Mature $\square$ Spent}

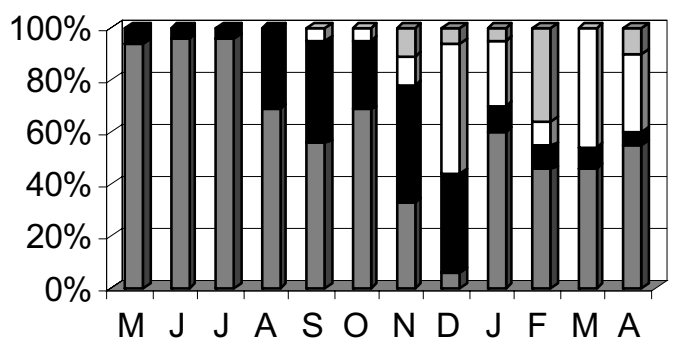

(a)

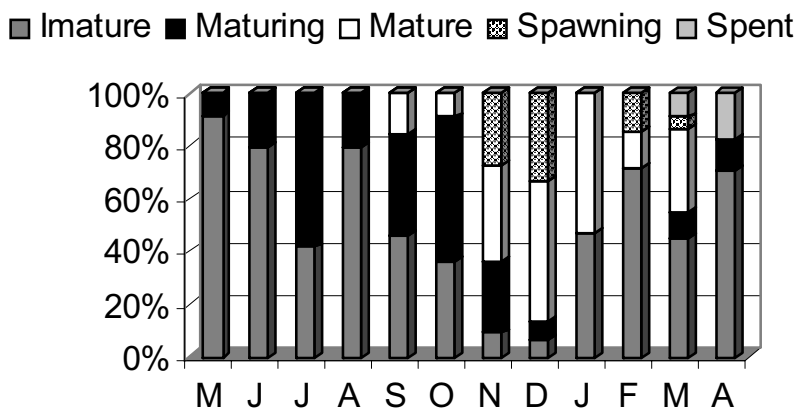

(b)

Fig. 4. Monthly variation of the gonadal maturation stages of Gymnotus aff. carapo in lagoa Verde, Itapuã State Park. (a) Males, (b) Females. 
The non-parametric Spearman correlation test did not show statistical significance between males and females gonadosomatic index and somatic factors $(p<0.05)$ (Table 1$)$. Male gonadosomatic index showed positive correlation with dissolved oxygen and negative correlation with conductivity. Female gonadosomatic index showed positive correlation

\section{Water Temperature}

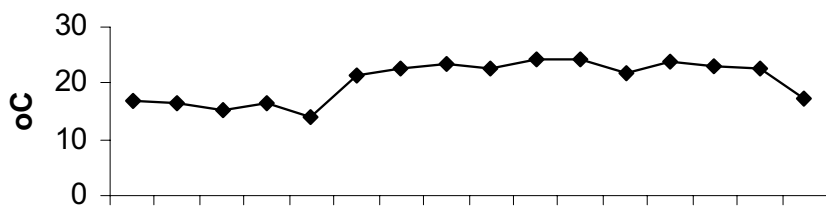

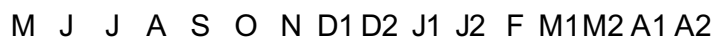

\section{Conductivity}

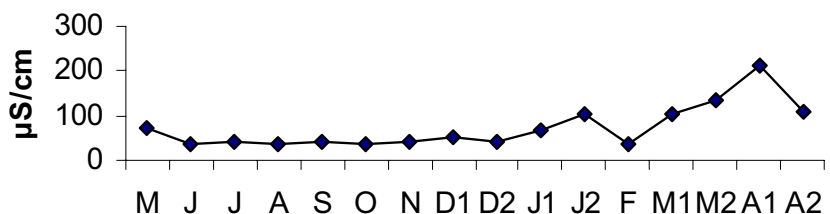

Dissolved Oxygen

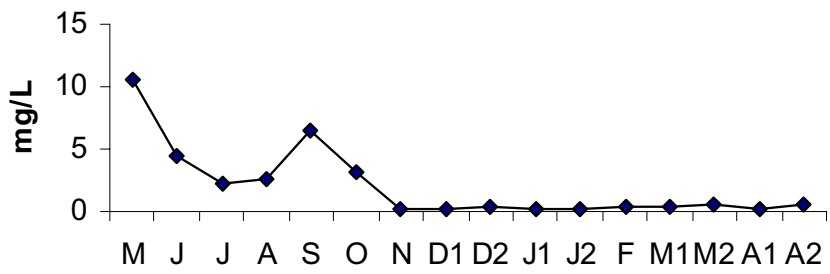

Depth

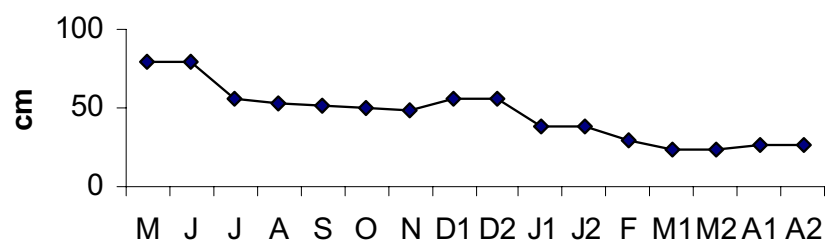

Photoperiod

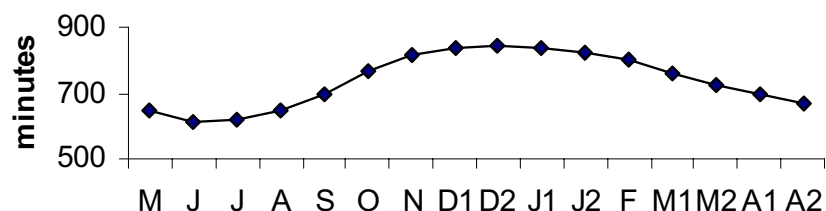

Fig. 5. Monthly variation of abiotic factors in lagoa Verde, Itapuã State Park. with temperature and photoperiod, and negative correlation with dissolved oxygen (Table 2, Fig. 5).

The mean absolute fecundity of females between 213.2$280.5 \mathrm{~mm}$ total length reached $915.3 \pm 202$. The diameter of vitellogenic oocytes reached $1.7 \mathrm{~mm}$. The mean relative fecundity estimated was 0.2 oocytes/mg of body weight (Table 3 ).

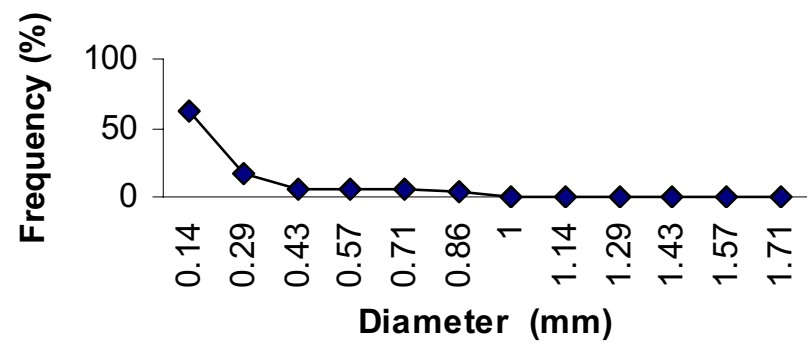

Mature $(n=10)$

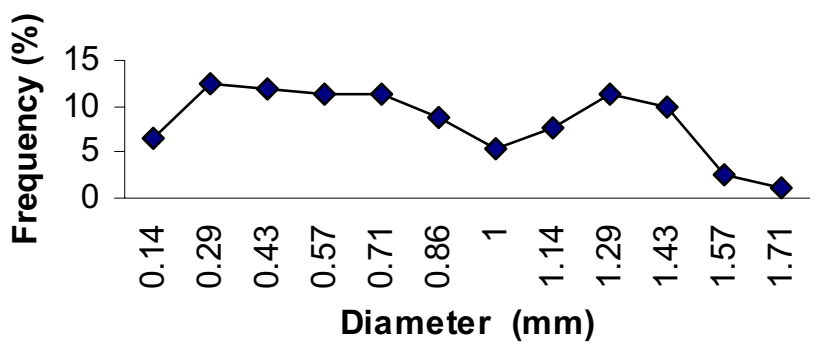

Spawning $(n=7)$

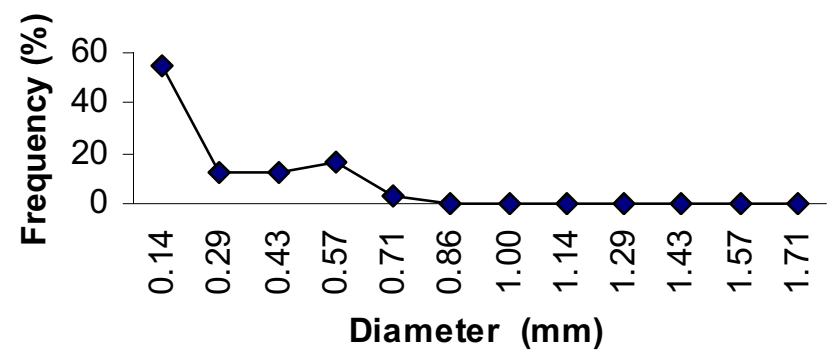

Spent $(n=7)$

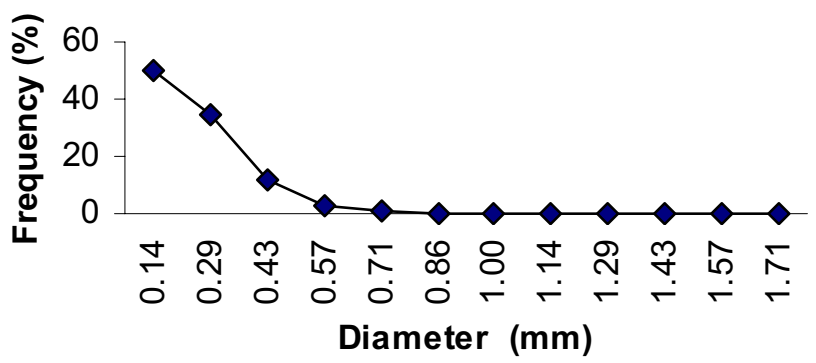

Fig. 6. Relative frequency distribution of oocyte diameter in four different stages of Gymnotus aff. carapo gonadal maturation in lagoa Verde, Itapuã State Park. 


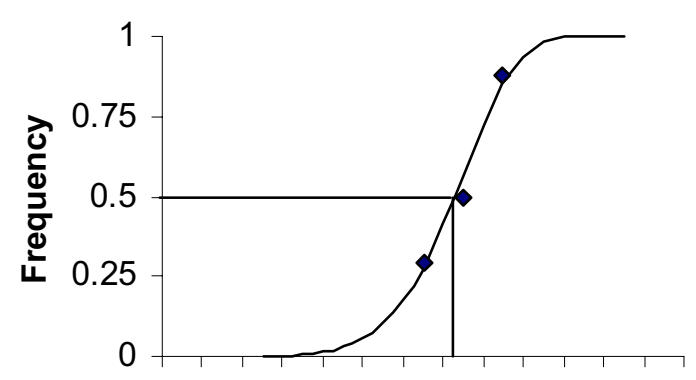

(a)

\section{Length classes ( $\mathrm{mm}$ )}

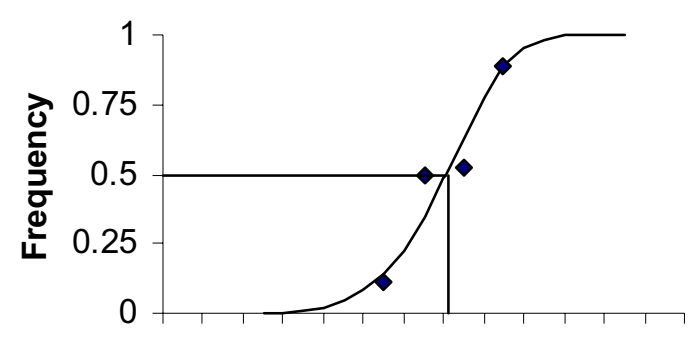

(b)

\section{Length classes $(\mathrm{mm})$}

Fig. 7. Size of first gonadal maturation of Gymnotus aff. carapo in the lagoa Verde, Itapuã State Park. (a) males; (b) females.

Spawning type was considered multiple, and oocyte development is synchronic in two groups, according to the distribution of absolute frequency of oocytes diameter (Fig. 6). Moreover, portions of oocytes in different maturation classes will be released in different moments until the end of reproductive cycle. Histological sections confirmed the gonadal maturation stage considered "spawning", and a relatively long reproductive cycle that implies multiple spawning.

The size of first gonadal maturation was estimated in 146 $\mathrm{mm}$ to males and $141 \mathrm{~mm}$ to females (Fig. 7).

The sex ratio was 1:1 throughout the sampling period $\left(\chi^{2}\right.$ $=2.97 ; \mathrm{p}>0.05)($ Fig. 8$)$, with a male bias only in smaller size classes $\left(\chi^{2}=5 ; \mathrm{p}<0.05\right)$ (Fig. 9).

\section{Discussion}

The formulation of an accurate gonadal maturation scale is very important to understand the reproductive ecology (Giora, 2004). Such scale must be simple and applicable to the target species. According to Vazzoler (1996), to delimitate the reproductive cycle of a species it is necessary to balance the subjectivity of macroscopic classifications, and time and cost of detailed microscopic analysis.

We herein described reproductive traits of a population of Gymnotus from laguna dos Patos drainage, southern Brazil, identified as belonging to the Gymnotus carapo speciesgroup of Albert (2001), and possibly representing a new species. Most comparative data available are those describe in

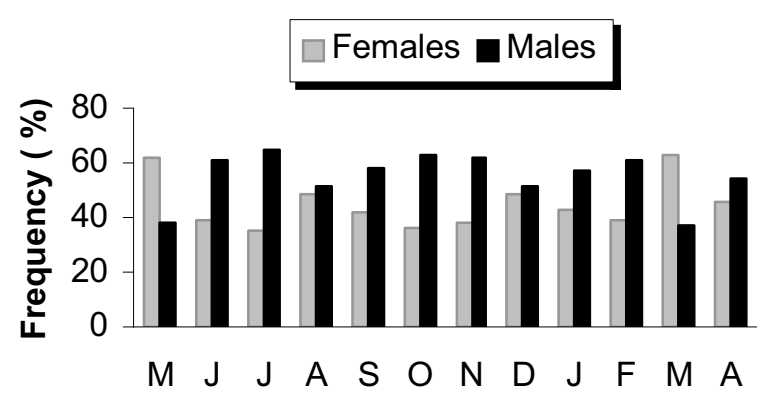

Fig. 8. Monthly variation of relative frequencies of males and females of Gymnotus aff. carapo in lagoa Verde, Itapuã State Park.

several papers by Barbieri \& Barbieri for "Gymnotus carapo", based in a population of Gymnotus from the Represa do Lobo reservoir, in São Paulo, Brazil, but that do not represent Gymnotus carapo sensu stricto, in the restrictive definition of the species given by Albert \& Crampton (2003). Thus, compared populations from lagoa Verde in the Itapuã State Park, Rio Grande do Sul state, and from Represa do Lobo, São Paulo, Brazil, may represent two different species.

Barbieri \& Barbieri (1985) describe mature females from Represa do Lobo population were captured between September and February, when relative frequencies of mature and spawning ovaries were greater. Similar data were obtained in the lagoa Verde population, with increased relative frequencies of mature and spawning ovaries between September and March.

Barbieri \& Barbieri (1984b) observed few differences in size and color of testes during their study, and described a higher spermatogenic activity between September and January, reaching a peak in October and November. In the present study, the testes of Gymnotus population from lagoa verde had a similar development and morphology to that described by Barbieri \& Barbieri (1984b) for the population from Represa do Lobo, with gonadal activity during all sampling period, and reaching higher activity between September/2003 and April/2004, when there was a higher relative frequency of

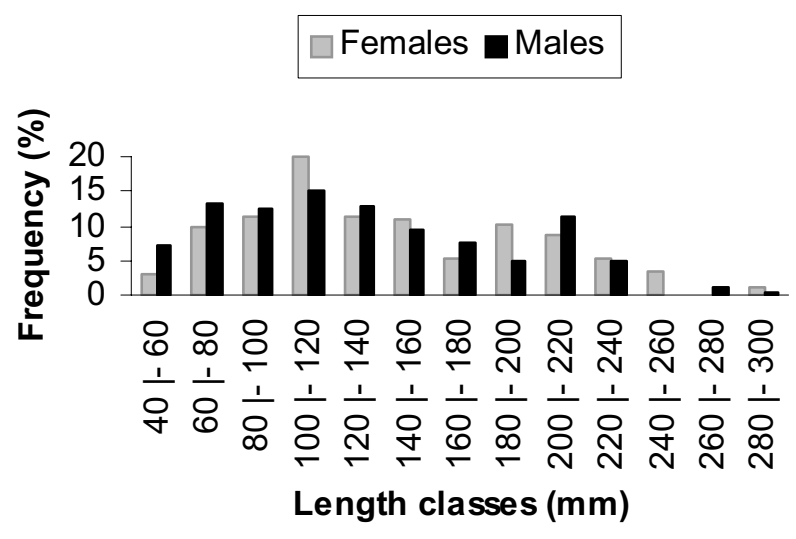

Fig. 9. Relative frequency distribution of males and females of Gymnotus aff. carapo by total length classes in lagoa Verde, Itapuã State Park. 
Table 3. Total length (Lt), total weight (Wt), gonadosomatic index (IGS), absolute fecundity (FA) and relative fecundity (FR) of 10 Gymnotus aff. carapo females in lake Verde, Itapuã State Park.

\begin{tabular}{cccccc}
\hline & Lt $\mathbf{( ~ m m})$ & Wt $\mathbf{( g )}$ & IGS (\%) & FA & FR \\
\hline 204.36 & 30.4023 & 4.76 & 665 & 0.22 \\
213.2 & 39.9972 & 5.19 & 922 & 0.23 \\
216.88 & 36.2458 & 6.32 & 790 & 0.22 \\
219.5 & 41.7975 & 5.52 & 1308 & 0.31 \\
& 223.24 & 44.7922 & 5.18 & 703 & 0.16 \\
& 224.86 & 44.769 & 6.8 & 1111 & 0.25 \\
& 230.25 & 43.8944 & 6.01 & 1017 & 0.23 \\
& 237.53 & 54.4258 & 4.67 & 719 & 0.13 \\
& 254.82 & 55.2226 & 6.31 & 972 & 0.18 \\
& 280.5 & 84.4788 & 5.43 & 946 & 0.11 \\
\hline Mean & $\mathbf{2 3 0 . 5 1}$ & $\mathbf{4 7 . 6 0}$ & $\mathbf{5 . 6 2}$ & $\mathbf{9 1 5 . 3}$ & $\mathbf{0 . 2 0}$ \\
\hline
\end{tabular}

mature males. In relation to gonadal maturation stage, the testes were more difficult to be differentiated macroscopically.

The population from lagoa Verde showed a seasonal and long reproductive cycle, between November/2003 and March/ 2004, corresponding to spring-summer season. Barbieri \& Barbieri (1983a) have observed a short reproduction cycle for the Represa do Lobo population, occurring between October and December, similarly to data in Vazzoler (1996). Barbieri and Barbieri's studies occurred in lower latitudes, where the climatic changes are relatively minor, allowing a shorter spawning period, with more stable conditions for larvae development. Silva et al. (2003) inferred a reproductive cycle for $B$. pinnicaudatus between November and January. However, the reproductive cycle could be longer because the reproductive biology was not studied in detail. Giora (2004) has estimated a long reproductive cycle for E. trilineata, between October/ 2002 and February/2003, following the same pattern obtained in the present study. Winemiller \& Taphorn (1989), observed that G. carapo population from Venezuela also has a long reproductive cycle despite the great difference of latitude and rainfall between sample sites.

The timing of reproduction in female teleosts may be viewed as the product of numerous biotic and abiotic stimulus that exert both long-term effects in ovarian growth and short-term effects at the end of maturation and ovulation of the oocytes (Stacey, 1984). Kirschbaum (1979) has experimentally observed that gonadal maturation of E. virescens is influenced by abiotic factors such as decreases in conductivity and $\mathrm{pH}$, and increases in water level, as well as rainfall simulation. Silva et al. (2003) showed that breeding in $B$. pinnicaudatus was coincident with higher water temperatures, large daily changes, low water conductivity and extreme photoperiod. Barbieri \& Barbieri (1983a) estimated that mean gonadosomatic index of G. carapo in Represa do Lobo has a direct relation with water temperature, dissolved oxygen, rainfall and photoperiod.

The principal factors determining the survival of fish embryos are respiration and relation with predators (Kryzhanovskii, 1949). The mean gonadosomatic index of $G$. aff. carapo females have negative correlation with dissolved oxygen, suggesting that spawning takes place even in low levels of oxygen. The survival of embryos could be affected by this factor. Parental care in $G$. aff. carapo population from lagoa verde was not observed in this study, but it is known to occur in other species of the genus (Kirschbaum \& Wieczorec, 2002; Kirschbaum \& Schugardt, 2003; Crampton \& Hopkins, 2005). According Vazzoler (1996) territorial species like Gymnotus, that have parental care, can provide oxygen to eggs, embryos and larvae generating water currents. An observed decrease in mean stomach repletion index in males after November/2003 could be related to parental care.

Reproductive seasonality in fishes from temperate regions, where rainfall cycles are not evident, is mainly related to temperature, photoperiod and food supply (McKaye, 1984; Payne, 1986). Here, we observed that water temperature has positive correlation with gonadosomatic index of $G$. aff. carapo females from lagoa Verde. This corroborates similar findings described by Barbieri \& Barbieri (1983a) in the Gymnotus from Represa do Lobo.

The increase of day length is perceived by photoreceptors in the skin of fishes, causing decrease in production of melatonin, which is a reproduction inhibitor (Jobling, 1995; Bromage et al., 2000).

Studies in southern Brazil (Azevedo et al., 2000; Lampert, 2003; Giora, 2004; Gonçalves et al., 2005) suggest the reproductive cycle is strongly correlated to the photoperiod. The increase of temperature closely related with increase in photoperiod unleashes gonadal development (Vazzoler, 1996).

Decreases in conductivity are related with gonadal maturation in Gymnotus carapo in captivity (Kirschbaum \& Schugardt, 2003). Males of $G$. aff. carapo in the present study have higher values of mean gonadosomatic index when conductivity is lower. A possible reason is that the range of electric field increases when the conductivity is low, increasing the chances of conspecific interaction between males and females, facilitating reproduction.

The fecundity of a population or species is automatically adjusted to food supply by metabolism (Nikolskii, 1969). The fecundity depends on the availability of body cavity keep mature ovaries and on the size of oocytes (Vazzoler, 1996). Moreover, greater fishes tend towards to have higher fecundity. Gymnotus aff. carapo have a low mean absolute fecundity, comparing with data from Barbieri \& Barbieri (1982), that estimated to G. carapo 2192 oocytes in 1978/79 and 1791 oocytes in 1979/80 reproductive cycles. The same authors estimated absolute fecundity to exceed 3000 oocytes $(25.5-46 \mathrm{~cm}$ Total Length) in 1978/79 reproductive cycle, higher than $G$. aff. carapo. Vazzoler (1996) has estimated the absolute fecundity in 3000 oocytes for G. carapo $(32.9 \mathrm{~cm}$ maximum total length) presenting parental care. The lower fecundity of $G$. aff. carapo in the present study could be related to multiple spawning or parental care, although Vazzoler (1996) points out to parental care with higher fecundity. Gymnotus aff. carapo have a long reproductive cycle, 2 months longer than other studied species of Gymnotus in Brazil, allowing spawning of a larger amount of oocytes by reproductive cycle, what could explain the lower absolute fecundity. Some reproduc- 
tive features, for instance parental care, spawning type, migration and fecundation type can affect fecundity. Species that offer high rate of fecundation of oocytes or egg/larvae survival, usually present lower fecundity values (Vazzoler \& Menezes, 1992).

The large diameter of mature oocytes is another factor that influences values of absolute fecundity in $G$. aff. carapo. However, Vazzoler (1996) has estimated that G. carapo females have an absolute fecundity of some 3000 oocytes (32.9 cm total length), with $2.7 \mathrm{~mm}$ greatest diameter of oocytes, contrasting with the diameter estimated to the present study, i.e. $1.7 \mathrm{~mm}$. Moreover, Barbieri \& Barbieri (1982) have determined G. carapo females with 3000 oocytes of absolute fecundity (46 cm total length), have $3.6 \mathrm{~mm}$ greatest diameter of oocytes. Therefore, the diameter of mature oocytes of $G$. aff. carapo in the present study could not impede it to have a higher mean absolute fecundity, implying that the reproductive cycle and spawning type could determine a lower absolute fecundity.

The analysis of relative fecundity aims to reduce the influence of body size of fish in fecundity, allowing comparison between individuals of different sizes. Relative fecundity is an indirect way to estimate the energetic effort used to produce oocytes (Giora, 2004). The same author has estimated to E. trilineata a mean relative fecundity of 0.27 oocytes/ $\mathrm{mg}$ body weight. Due to singular anatomy of gymnotiforms, a low relative fecundity is expected because the size of body cavity constrains high production of oocytes.

Multiple spawning represents a mechanism by which some species increase the number of oocytes produced in a reproduction cycle. This increase is higher than what it is presumed by the fish size, when we consider that the fecundity depends on total length (Vazzoler, 1996). Gymnotus aff. carapo can reach almost $30 \mathrm{~cm}$, but the size of body cavity could be limiting the bulk of mature ovaries. Barbieri \& Barbieri (1982), Vazzoler (1996), Nakatani et al. (2001), and Kirschbaum \& Schugardt (2003) concluded that G. carapo is a multiplespawner as also observed in the present study.

The size of first gonadal maturation is a variable reproductive tactics, because it is closely related to growth, presenting spatial-temporal intraspecific variation related to biotic and abiotic conditions of the occupied area or period that the population is submitted to these factors (Vazzoler, 1996). Males and females of $G$. aff. carapo presented a similar size of first gonadal maturation. Nakatani et al. (2001) observed that the size of first maturation of Gymnotus cf. carapo is $141 \mathrm{~mm}$, similarly to the present study, demonstrating that Gymnotus species have similar reproductive features. Barbieri \& Barbieri (1983a) estimated the size of first gonadal maturation to $G$. carapo females is $24.8 \mathrm{~cm}$, higher than the one estimated to the present study. These authors observed that females of $G$. carapo could reach $50 \mathrm{~cm}$ total length, and the size of first gonadal maturation could occur in larger sizes.

In the greatest part of natural populations of fishes, the observed sex ratio is $1: 1$, but variations can occur when one of the sexes have particular advantage (Reay, 1989).
According to Vazzoler (1996), a sex ratio 1:1 was observed in the fish populations in several cases, but when the analysis is made by total length classes, female predominance can occur in greater length classes, because females have a higher growth taxa than males, reaching larger sizes at the same age. Giora (2004) observed that males of E. trilineata tend to be larger than females. This feature is not observed in this study because a predominance of males in 40-60 mm length class was observed. Relevant difference in relative frequency between sexes in other classes was likewise not observed.

\section{Acknowledgements}

We acknowledge Luiz R. Malabarba for helping in fieldwork and systematics, Will Crampton in EOD analysis that helped the recognition of the species, Fábio F. Lopes in histology and colleagues from the laboratories of Ichthyology and Herpetology at UFRGS that helped in fieldwork.

\section{Literature Cited}

Adebisi, A. A. 1987. The relationships between fecundities, gonadosomatic indices and egg sizes of some fishes of Ogun River, Nigéria. Archiv fuer Hydrobiology, 111(1):151-156.

Albert, J. S. 2001. Species diversity and phylogenetic systematics of American knifefishes (Gymnotiformes, Teleostei). Miscellaneous Publications, Museum of Zoology, University of Michigan, 190:1-27.

Albert, J. S. \& W. G. R. Crampton. 2003. Seven new species of the Neotropical electric fish Gymnotus (Teleostei: Gymnotiformes) with redescription of G. carapo (Linnaeus). Zootaxa, 287:1-54.

Azevedo, M. A. , L. R. Malabarba \& C. B. Fialho. 2000. Reproductive biology of the inseminated Glandulocaudine Diapoma speculiferum Cope, 1854 (Actinopterygii: Characidae). Copeia, 2000(4):983-989.

Barbieri, G. \& M. C. Barbieri. 1982. Fecundidade e tipo de desova de Gymnotus carapo Linnaeus, 1758 na represa do Lobo, estado de São Paulo (Pisces, Gymnotidae). Spectrum: Jornal Brasileiro de Ciência, 2(7):25-29.

Barbieri, G. \& M. C. Barbieri. 1983a. Dinâmica da reprodução de Gymnotus carapo na represa do Lobo, estado de São Paulo. Influência de fatores abióticos (Pisces, Gymnotidae). Tropical Ecology, 24(2):244-259.

Barbieri, G. \& M. C. Barbieri. 1983b. Growth and first sexual maturation size of Gymnotus carapo Linnaeus, 1758 in the Lobo reservoir (state of São Paulo, Brazil) (Pisces: Gymnotidae). Revue d'Hydrobiologie Tropicale, 16(2):195-201.

Barbieri, G. \& M. C. Barbieri. 1984a. Crescimento de Gymnotus carapo Linnaeus, 1758 na represa do Lobo, estado de São Paulo, pelo método da distribuição da freqüência de comprimento (Pisces, Gymnotidae). Revista Brasileira de Biologia, 44(3):239246.

Barbieri, M. C. \& G. Barbieri. 1984b. Reprodução de Gymnotus carapo Linnaeus, 1758 na represa do Lobo (SP). Morfologia e histologia de testículo. Variação sazonal. (Pisces, Gymnotidae). Revista Brasileira de Biologia, 44(2):141-148.

Barbieri, G. \& M. C. Barbieri. 1984c. Note on nutritional dynamics of Gymnotus carapo Linnaeus, 1758 from the Lobo reservoir, São Paulo State, Brazil. Journal of Fish Biology, 24:351-355. 
Barbieri, M. C. \& G. Barbieri. 1985. Reprodução de Gymnotus carapo Linnaeus, 1758 na represa do Lobo (SP). Morfologia e histologia de ovário. Variação sazonal. (Teleostei, Gymnotidae). Revista Brasileira de Biologia, 45(1/2):3-12.

Bennett, M. V. L. 1971. Eletric organs. In: Hoar, W. S. \& D. J. Randall. 1971. Academic press, New York. P. 347-484.

Bromage, N. , M. Porter \& C. Randall. 2000. The environmental regulation of maturation in farmed finfish with special reference to the role of the photoperiod and melatonin. Aquaculture, 197(2001):63-98.

Crampton, W. G. R. 1996. Gymnotiform fish: An important component of Amazonian floodplain fish communities. Journal of Fish Biology, 48:298-301.

Crampton, W. G. R. 1998. Effects of anoxia on the distribution, respiratory strategies and electric diversity of gymnotiform fishes. Journal of Fish Biology, 53(A):307-330

Crampton, W. G. R. \& C. D. Hopkins. 2005. Nesting and paternal care in the weakly electric fish Gymnotus (Gymnotiformes: Gymnotidae) with descriptions of larval and adult electric organ discharges of two species. Copeia, 2005(1):48-60.

Curtis, C. C. \& P. K. Stoddard. 2003. Mate preference in female electric fish, Brachyhypopomus pinnicaudatus. Animal Behaviour, 66:329-336.

Giora, J. 2004. Biologia reprodutiva e hábito alimentar de Eigenmannia trilineata López e Castello, 1966 (Teleostei, Sternopygidae) do Parque Estadual de Itapuã, Rio Grande do Sul, Brasil. Unpublished Ms. C. Thesis. Universidade Federal do Rio Grande do Sul. 91 p.

Gonçalves, T. K. , M. A. Azevedo, L. R. Malabarba \& C. B. Fialho. 2005. Reproductive biology and development of sexually dimorphic structures in Aphyocharax anisitsi (Ostariophysi: Characidae). Neotropical Ichthyology, 3(3):433-438.

Jobling, M. 1995. Environmental Biology of Fishes. Chapman \& Hall, London, 455 p.

Kirschbaum, F. 1979. Reproduction of the weakly electric fish Eigenmannia virescens (Rhamphichthyidae, Teleostei) in captivity. Behavioral Ecology and Sociobiology, 4:331-355.

Kirschbaum, F. \& C. Schugardt. 2003. Reproductive strategies and developmental aspects in mormyrid and gymnotiform fishes. Journal of Physiology. 96:557-566.

Kirschbaum, \& L. Wieczorek. 2002. Entdeckung einer neuen Fortpflanzungs-strategie bei südamerikainischen Messerfischen (Teleostei: Gymnotiformes: Gymnotidae): Maulbrüten bei Gymnotus carapo. Verhalten der Aquarienfische. 2, 99-107.

Kryzhanovskii, S. G. 1949. Ecological and morphological trends in development of the Cyprinoidae and Siluroidae. Trudy Institute Morfology Zhivotn Akademic Nauk. SSSR, Nro 1.

Lampert, V. R. 2003. Biologia reprodutiva de duas espécies do gênero Bryconamericus (Characidae: Tetragonopterinae) dos sistemas dos rios Jacuí e Uruguai, RS. Unpublished MsC. Thesis, Universidade Federal do Rio Grande do Sul, Porto Alegre. 73p.
Lundberg, J. G. \& C. Weber. 1987. A major food web component in the Orinoco river channel: evidence from planktivorous electric fish. Science. 237:81-83.

Mago-Leccia, F. 1994. Eletric fishes of continental waters of America. Biblioteca de la Academia de Ciencias Físicas, Matemáticas Y Naturales. Caracas, Venezuela. 206 p.

McKaye, K. R. 1984. Behavioral aspects of cichlids reproductive strategies: patterns of territoriality and brood defense in Central American substratum spawners and African mouth brooders. Pp. 245-273. In: Potts, G. W. \& R. J. Wooton (Eds). Fish reproduction: strategies and tatics. London, Academic Press, $410 \mathrm{p}$.

Nakatani, K. , A. A. Agostinho, G. Baumgartner, A. Bialetzki, P. V. Sanches, M. C. Makrakris \& P. S. Pavanelli. 2001. Ovos e larvas de peixes: desenvolvimento e manual de identificação. Maringá. Editora da Universidade. 378p.

Nikolskii, G. V. 1969. Theory of fish population dynamics as the biological background for rational exploitation and management of fishery resources. Edinburgh, Oliver \& Boyd Ltda., 323 p.

Nikolskii, G. V. 1963. The ecology of fishes. London. Academic Press, $353 \mathrm{p}$.

Payne, A. I. 1986. The ecology of tropical lakes and rivers. New York: John Wiley. 310p.

Reay, P. J. 1984. Reproductive tatics: a non-event in aquaculture? Pp. 291-309. In: Potts, G. W. \& M. N. Wooton (Eds. ) Fish reproduction: strategies and tatics. London, academic Press, $410 \mathrm{p}$.

Silva, A. , L. Quintana, M. Galeano \& P. Errandonea. 2003. Biogeography and breeding in Gymnotiformes from Uruguay. Environmental Biology of Fishes. 66:329-338.

Stacey, N. E. 1989. Control of the timing of ovulation by exogenous and endogenous factors. Pp. 207-221 In: Potts, G. W. \& R. J. Wootton. Fish reproduction: strategies and tactics. London. $410 \mathrm{p}$.

Vazzoler, A. E. A. M. 1996. Biologia da reprodução de peixes teleósteos: teoria e prática. Maringá, Editora da Universidade, $169 \mathrm{p}$.

Vazzoler, A. E. A. M. \& N. A. Menezes. 1992. Síntese de conhecimentos sobre o comportamento reprodutivo dos Characiformes da América do Sul (Teleostei, Ostariophysi). Revista Brasileira de Biologia, 52(4):627-640.

Winemiller, K. O. \& D. C. Taphorn. 1989. La evolucion de las estrategias de vida en los peces de los llanos occidentals de Venezuela. Biollania, 6:77-122.

Received June 2005 Accepted August 2006 